\title{
A Legitimidade da Concessão de Medidas Cautelares na Ação Direta de Inconstitucionalidade: uma análise a partir da teoria de Víctor Comella
}

\author{
The Legitimacy of Granting Precautionary Measures in the Direct Action of \\ Unconstitutionality: an analysis based on Victor Comella's theory
}

Juliana Rodrigues Freitas

Resumo: O controle de constitucionalidade das normas é utilizado para retirar do sistema jurídico as normas incompatíveis com a ordem estabelecida pela Constituição Federal, bem como é fundamental para o equilíbrio do Estado Democrático de Direito, a partir da proteção do equilíbrio das funções desse Estado e por garantir a observância dos direitos previstos no plano constitucional, motivos pelos quais (dentre outros) deve ser considerado também como um dos pilares do Estado Democrático de Direito. No modelo brasileiro da Ação Direta de Inconstitucionalidade é permitida a concessão de medidas cautelares, com o desiderato de declarar, provisoriamente, a inconstitucionalidade das normas que, aprovadas por um processo democrático de deliberação, deveriam ter sobre si presunção moderada de constitucionalidade, o que, de per si, não autorizaria o juiz a considerar cautelarmente a incompatibilidade do documento normativo ao texto constitucional, de acordo com o que preleciona Víctor Comella. Diante desse contexto, a concessão de cautelares em sede da Ação Direta de Inconstitucionalidade deveria ser considerada incompatível com os fundamentos constitucionais do Estado brasileiro

Palavras-chave: Ação Direta de Inconstitucionalidade. Medidas Cautelares. Constitucionalidade.
Abstract: The judicial review of the standards is used to remove the legal system standards incompatible with the order established by the Federal Constitution as well, is crucial to the democratic state, from, among others, the balance of protection of functions of that State and for ensuring observance of the rights provided for in the constitutional level, the reasons should be considered as Judicial Review also as one of the pillars of the democratic state of law. Direct Action of Unconstitutionality in the Brazilian model allows the provisionals measures, with the focus to declare provisionally the unconstitutionality of the rules adopted by a democratic process of deliberation, should have about them a moderate presumption of constitutionality, which of itself, would not authorize the judge to cautiously consider the incompatibility of the normative document to the Constitution, according to which preleciona Victor Comella. In this context, the granting of interim headquarters in the Direct Action of Unconstitutionality should be found to violate the constitutional foundations of the Brazilian state.

Keywords: Direct Action of Unconstitutionality. Provisionals Measures. Constitutionality.

Artigo recebido em 9 jan. 2017 e aprovado em 12 maio 2017. 


\section{Introdução}

A verificação de constitucionalidade de leis ou atos normativos é um dos instrumentos utilizados para a defesa da ordem jurídica, por meio da qual é averiguada a compatibilidade de diplomas infraconstitucionais aos preceitos que compõem a Constituição Federal.

O controle concentrado de constitucionalidade de normas (um dos instrumentos de proteção da unidade jurídica e mais precisamente um dos pilares de um Estado Democrático de Direito), a priori, manifesta-se por meio de ações próprias e específicas no sistema brasileiro de justiça constitucional, dentre as quais, a Ação Direta de Inconstitucionalidade.

A legislação que regulamenta a matéria, Lei n 9.868/1999, autoriza a concessão de provimentos de natureza provisória, as medidas cautelares, de modo que no exercício da jurisdição constitucional uma lei pode ser declarada provisoriamente incompatível com a Constituição Federal, esta, norma basilar e estruturante do ordenamento jurídico brasileiro.

Diante desse contexto, surgem questionamentos acerca da legitimidade democrática da concessão de medidas cautelares em sede de Ação Direta de Inconstitucionalidade, considerando a sua natureza provisória e a "afirmação" temporária proferida pelo Supremo Tribunal Federal de afronta à Constituição Federal brasileira.

Buscando fundamentos a partir da teoria desenvolvida por Víctor Ferreres Comella, este trabalho faz uma análise acerca da coerência da concessão de medidas cautelares na Ação Direta de Inconstitucionalidade, a qual tem por objetivo primeiro e maior é o de zelar pela aplicação e observância dos valores democráticos sobre os quais foi erigida a Constituição Federal de 1988.

\section{Controle Concentrado de Constitucionalidade de Normas}

Os mecanismos de proteção da unidade jurídica - elaborados com o intuito de excluir do sistema de normas, leis ou atos que contrariem preceitos da Carta Magna, garantindo-se, assim, a prevalência do querer social representado pela manifestação do constituinte originário - surgem em razão do ordenamento jurídico compreender uma Carta fundamental caracterizada por sua rigidez sendo, por isso, integrado por normas de graus hierárquicos diversos, situando-se a Constituição fundamento maior de validade formal e material do conjunto normativo, no ápice desse sistema. 
A verificação concentrada da constitucionalidade de leis ou atos normativos é um dos instrumentos utilizados para a defesa da ordem jurídica, através da qual é averiguada a compatibilidade de diplomas infraconstitucionais aos preceitos que compõem a Constituição, por meio de ações próprias, com procedimentos específicos, em uma via principal e direta de atuação do órgão de cúpula do Judiciário ou de um órgão criado para estsa finalidade específica, como o Tribunal ou Corte Constitucional.

A origem desse controle remonta ao ano de 1920, ano em que foi elaborada a Constituição austríaca baseada no projeto desenvolvido pelo jusfilósofo Hans Kelsen, que, por sua vez, identificou a necessidade de serem eliminadas as incompatibilidades surgidas entre os textos constitucionais dos Estados-membros e os da União naqueles países de formação federativa, bem como as contradições jurisprudenciais, inevitáveis caso tal controle fosse realizado incidentalmente por todos os juízes ou tribunais.

O sistema austríaco atribuiu ao Tribunal Constitucional - Verfassungsgerichtshof - a notável função de admitir (in) constitucionalidade de uma norma integrante do plexo jurídico daquele país federado; esse Tribunal Constitucional, caracterizado pela sua independência e composto por cidadãos de destacável conhecimento jurídico que já haviam integrado a cúpula dos poderes Legislativo e Executivo, não deveria situar-se na esfera do Judiciário, justamente para que, assim, fosse preservado o princípio da harmonia e separação dos poderes.

Em outras palavras: os juízes integrantes do Judiciário não eram competentes para controlar a constitucionalidade das leis cuja aplicação se fazia imprescindível para a solução do caso sub judice, assim como não podiam suscitar à Corte Constitucional para fazê-lo. Deveriam, sim, adotar como válidas as leis formadoras do conjunto normativo, sem que pudessem, entretanto, deixar de aplicá-las se, acaso, duvidassem de sua compatibilidade ao texto constitucional.

A legitimidade para questionar a constitucionalidade de uma norma perante a Corte possuía caráter político, pois limitava-se aos governos Federal e Estaduais - Länder -, cujas atuações eram revestidas da mais ampla discricionariedade, pois, em regra, eram submetidas ao julgamento do Tribunal Constitucional apenas as matérias de interesse específico desses governos, ou seja, aquelas relacionadas às competências constitucionais.

Por via de consequência, restrito era o âmbito de atuação dessa Corte, que deixava de apreciar documentos normativos de importância 
singular para a sociedade, como os relativos aos direitos e às garantias individuais, permitindo, assim, a sua permanência no ordenamento jurídico, mesmo que inconstitucionais.

Em decorrência da revisão constitucional ocorrida no ano de 1929, ao lado desses órgãos políticos, tornaram-se legitimados para dirigirem-se à Corte Constitucional dois órgãos de cúpula do Judiciário, a Corte Suprema para causas civis e penais - Oberster Gerichtshof -, e a Corte Suprema para causas administrativas - Verwaltungsgerichtshof -, as quais atuavam diante da necessidade da aplicação de uma lei, de questionável constitucionalidade, para a solução de um caso concreto, devendo ser dirimida tal dúvida pelo Tribunal Constitucional, por intermédio de uma decisão vinculante ao Judiciário.

O inconveniente observado nesse procedimento é que todos os juízes deveriam aplicar a lei até o momento em que o processo subisse às instâncias superiores em grau de recurso, quando, somente então, a atuação do Tribunal Constitucional poderia ser suscitada.

Por outro lado, uma maior diversidade de matérias tornou-se objeto de apreciação da Corte Constitucional tendo em vista que toda e qualquer lei supostamente inconstitucional, e desde que imprescindível para a solução de uma demanda submetida aos Tribunais Superiores para causas civis e penais ou administrativas, poderia ser objeto de análise pelo Tribunal Constitucional. Assim, não apenas as leis regulamentadoras das competências constitucionais como também as demais que dispusessem, por exemplo, sobre direitos individuais, poderiam ter a sua inconstitucionalidade declarada pelo Verfassungsgerichtshof.

Os efeitos da sentença proferida declarando a existência do vício da ilegitimidade constitucional não deveriam retroagir para abarcar fatos que foram regulamentados pela lei em questão, a qual vinha sendo adotada como compatível com o sistema até o momento do julgamento pela Corte Constitucional.

A declaração da inconstitucionalidade de uma lei ou ato normativo não produziria, dessa feita, a sua nulidade de pleno direito, mas apenas a sua anulabilidade, pois o ingresso da norma no ordenamento jurídico garantiu a sua validade no sistema até o momento da verificação do vício da inconstitucionalidade decorrente da sentença proferida num determinado processo constitucional. 
Esse o entendimento esboçado por Kelsen (1999, p. 308) ao afirmar:

[...] a ordem jurídica não pode fixar as condições sob as quais algo que se apresente com a pretensão de ser uma norma jurídica tenha de ser considerado a priori como nulo, e não como uma norma que deve ser anulada através de um processo fixado pela mesma ordem jurídica.

A irretroatividade da declaração de inconstitucionalidade no modelo austríaco sofreu uma discreta graduação com o advento da reforma constitucional de 1929, a qual passou a admitir que diante do caso concreto que motivou o questionamento da constitucionalidade de uma lei, e unicamente em relação a esse, pudesse também incidir a decisão da Corte Constitucional. Tal flexibilidade gerou o inconveniente, porém, de que casos semelhantes àquele sobre o qual pairou a questão da inconstitucionalidade da norma não fossem também solucionados com base na decisão do Tribunal Constitucional, surgindo, dessa feita, disparidades no tratamento jurídico, com repercussões sociais negativas, tendo em vista a violação ao princípio da isonomia, o qual se traduz pela determinação da igualdade de tratamento àqueles que figurarem em situações equivalentes.

Em conformidade ao sistema austríaco, os efeitos da declaração de inconstitucionalidade se projetam para o futuro, a sua eficácia, portanto, flui a partir da data da publicação da sentença proferida pelo Tribunal Constitucional, ou em outro prazo fixado pela Corte, desde que não ultrapasse um ano dessa publicação, e são erga omnes, alcançando a todos indistintamente.

Cabe enfatizar que não somente na Áustria como nos demais países que adotaram esse modelo de controle de constitucionalidade de normas, dos quais o Brasil é um exemplo, o efeito erga omnes é conferido restritivamente à decisão contida na sentença, sendo atribuído o caráter inter partes à motivação, diversamente do que ocorre no controle difuso de constitucionalidade de normas ou modelo norte americano, no qual é atribuída eficácia erga omnes às razões que fundamentaram determinada decisão, permitindo que essa interpretação utilizada vincule a todos, restando às partes litigantes vincularem-se apenas ao teor da decisão. Tal característica permite que, em outro momento, a mesma lei possa ser questionada novamente, desde que os fundamentos desse novo questionamento sejam diversos daqueles já anteriormente declarados contrários aos preceitos fundamentais. (LLORENTE, 1997, 463/504). 
A fim de serem evitadas lacunas no ordenamento jurídico austríaco, admite-se o efeito repristinatório, com base no qual a regulamentação das relações sociais se realiza por um documento normativo que volta a viger após ter sido revogado por uma norma que, declarada inconstitucional, deve ser eliminada do ordenamento jurídico.

\subsection{Ação Direta de Inconstitucionalidade como Instrumento do Controle Concentrado de Constitucionalidade de Normas no Sistema Brasileiro}

O controle concentrado de constitucionalidade de normas é exercido, no Brasil, pelo Supremo Tribunal Federal, em relação a leis ou atos normativos federais ou estaduais perante a Constituição Federal, bem como pelos Tribunais de Justiça dos Estados em relação a leis ou atos normativos estaduais e municipais em face da Constituição Estadual, e, também, por razões que possam originar a intervenção federal nos estados, ou a intervenção estadual nos municípios, conforme preceituam os dispositivos 102, I, a; 125, \2ª; 34, VII, e 35, IV, da Constituição Federal de 1988.

A origem desse sistema remonta ao ano de 1965, quando da publicação da Emenda Constitucional no 16 , a qual atribuiu ao Supremo Tribunal Constitucional competência para processar e julgar representação contra a inconstitucionalidade de lei ou ato de natureza normativa federal ou estadual, encaminhada pelo Procurador-Geral da República (artigo 101, I k, da Constituição brasileira de 1946).

Antes dessa emenda havia apenas a regulamentação da representação interventiva, cujo objetivo era o de possibilitar a intervenção da União nos Estados, realizada quando atos fossem praticados em desconformidade com os dispositivos constitucionais e princípios federativos.

A legitimidade ativa para a propositura dessa representação se restringia ao Procurador-Geral da República - como membro do Ministério Público Federal nomeado chefe pelo Presidente da República, atuava, muitas vezes, de acordo com critérios e conveniências políticas ao promover a representação de inconstitucionalidade -, que deveria submeter ao Supremo Tribunal Federal a análise das alegações para a adoção da medida interventiva.

Sem inovações significativas na Constituição subsequente de 1967, nem na sua respectiva Emenda Constitucional no 01/69, foi a partir da Constituição de 1988 que o controle concentrado de normas assumiu 
proporções mais significativas, a iniciar pela ampliação do rol de legitimados a questionar a inconstitucionalidade de norma perante o Poder Judiciário, antes restrito ao chefe do Ministério Público Federal, conforme já mencionado.

Por intermédio do estatuto político de 1988, o Presidente da República, Mesas do Senado Federal, da Câmara dos Deputados, das Assembleias Legislativas e da Câmara Legislativa, os Governadores dos Estados e do Distrito Federal, o Conselho Federal da Ordem dos Advogados do Brasil, o partido político com representação no Congresso Nacional, e as confederações sindicais ou entidades de classe de âmbito nacional adquiriram, conforme previsão no artigo 103, a prerrogativa de ajuizar ação de inconstitucionalidade de leis ou atos normativos perante o Supremo Tribunal Federal.

A partir da Lei n 9.868, de 10 de novembro de 1999, que dispõe sobre o processo e julgamento das ações constitucionais de controle concentrado de constitucionalidade de normas, o efeito vinculante das suas decisões foi regulamentado, previsão essa questionável sob o ponto de vista da legitimidade constitucional visto ter atribuído ao Supremo Tribunal Federal uma função - ou o alcance de sua função - para além do previsto na Constituição Federal, norma responsável por regulamentar as competências titularizadas por esse órgão do Judiciário.

De toda forma, em 2004, em razão da reforma do Judiciário regulamentada em nível constitucional pela Emenda no 45, o artigo 102, no seu parágrafo $2^{\circ}$, sofreu alteração textual para admitir que as decisões definitivas de mérito proferidas pelo Supremo Tribunal Federal nas ações diretas de inconstitucionalidade e nas ações declaratórias de constitucionalidade produzirão eficácia contra todos, e efeito vinculante relativamente aos demais órgãos do Poder Judiciário e à administração pública direta e indireta, nas esferas federal, estadual e municipal.

Obviamente que atribuindo a esse texto uma interpretação sistemática, devemos entender que a eficácia erga omnes e o efeito vinculante das decisões proferidas em sede dessas ações constitucionais deverão também alcançar a administração pública direta e indireta no âmbito do Distrito Federal.

Como são ações que se instrumentalizam por meio de processos caracterizados pela sua objetividade, isto é, por inexistir um interesse 
subjetivo específico a ser tutelado mas sim a necessidade de se respeitar o princípio da supremacia constitucional, e, em especial, o de garantir a unidade jurídica ou a coesão sistêmico-normativa - poderíamos, nesse contexto, admitir o interesse subjetivo da sociedade em ser regida por normas compatíveis à ordem constitucional, expressão política maior de um corpo social -, não cabe a desistência nessas ações, pois a causa petendi limita-se a excluir do ordenamento jurídico lei ou ato normativo que transgrida preceitos constitucionais.

O relator do processo, in casu, pedirá informações à entidade ou ao órgão do qual emanou a norma impugnada, as quais deverão ser prestadas no prazo de 30 (trinta) dias, contados da data do recebimento do pedido (artigo 6º, parágrafo único, Lei n 9.868/99). Na Ação Direta de Inconstitucionalidade, após serem prestadas as devidas informações, serão ouvidos, no prazo de 15 (quinze) dias, o Advogado Geral da União e o Procurador-Geral da República.

Em conformidade ao artigo 27, da Lei $n^{\circ} 9.868 / 99$, por maioria de dois terços dos seus Ministros, a Corte Suprema brasileira poderá aplicar a modulação dos efeitos das suas decisões, seja no tocante ao aspecto temporal seja no subjetivo. Isso significa dizer que o Supremo Tribunal Federal poderá restringir os efeitos da declaração ditada, decidindo que a sua eficácia seja determinada pelo trânsito em julgado da decisão ou em outro momento fixado pelos seus Ministros - modulação temporal -, como também, com o objetivo de garantir a isonomia das relações sociais amparadas juridicamente, poderão os Ministros determinar que, os efeitos da sua decisão que, originariamente deveriam alcançar a todos indistintamente, com base no seu caráter erga omnes, podem alcançar somente uma parcela da sociedade, mais precisamente, aquela que esteve direta e imediatamente sujeita à vigência da norma declarada inconstitucional pelo Supremo Tribunal Federal - modulação subjetiva.

\section{Concessão de Medida Cautelar na Ação Direta de In- constitucionalidade}

A discussão acerca da possibilidade de concessão de medidas cautelares nas ações constitucionais remonta ao ano de 1975, quando a Associação dos Magistrados do Estado do Rio de Janeiro, por intermédio do Procurador-Geral da República, provocou a atuação do Supremo Tribunal 
Federal mediante a Representação n⿳⺈ 933, com o intuito de obter declaração de inconstitucionalidade, com pedido de medida preventiva, de algumas das disposições contidas na Resolução $n^{\circ}$ 01/75, do Tribunal de Justiça daquele Estado, as quais comprometiam suas garantias asseguradas constitucionalmente.

Até então, não havia sido regulamentada a possibilidade de o Supremo Tribunal Federal conceder medidas cautelares em Representações de Inconstitucionalidade. Aliás, importante enfatizar que tanto a Carta de 1967, como a sua posterior Emenda Constitucional nº 01, de 1969, representavam a fonte do poder autoritário exercido pelos militares àquela época, quando o princípio da legalidade cedeu espaço à satisfação dos interesses ditatoriais.

Os argumentos do relator do processo, Ministro Thompson Flores, caminharam em favor da concessão da medida, no sentido de admitir que, se compete única e exclusivamente ao Judiciário proferir, de modo irrecorrível, a declaração da (in)constitucionalidade de uma lei ou ato normativo, nada mais lógico que esse órgão, evitando a formação de situações de difícil reparação, se adiante na prestação final e obste a execução da lei viciada.

O Ministro Rodrigues Alckmin, também favorável à concessão da medida preventiva, alegou em seu voto que nenhum juiz deveria proferir uma sentença ou ser compelido a fazê-lo ciente de que essa não deva produzir seus efeitos ou, dificilmente, venha a produzi-los. Daí a necessidade desse poder acautelatório e geral, que é inerente ao próprio exercício da função, e um dos tipos fundamentais de tutela jurídica, porquanto a cautela conduz a evitar que uma sentença ou uma decisão não produza, sobretudo, seus efeitos normais.

Contrário ao deferimento da medida, o Ministro Xavier Albuquerque entendeu que se o Supremo Tribunal Federal, ao julgar a representação em definitivo, declarasse inconstitucionais os preceitos questionados, a suspensão liminar ou a sua não suspensão não alteraria a eficácia do julgamento, pois, segundo ele, as normas seriam tidas por inconstitucionais e, por isso, direitos de nenhuma espécie seriam constituídos tendo como base jurídica a referida norma; se atos administrativos fossem praticados, deveriam ser desfeitos, porque fundados em lei declarada inconstitucional. 
Ainda nos autos dessa mesma Representação, o Ministro Eloy da Rocha votou também desfavoravelmente à concessão da medida preventiva, por entender que é da competência do Judiciário a declaração da inconstitucionalidade de uma norma, mas não a suspensão da sua execução, atividade que integra o rol de competências constitucionais atribuídas ao Senado Federal. Em assim sendo, ao deferir o pedido acautelatório, estaria o Judiciário atuando de forma a extrapolar os limites que a Constituição traçou para o exercício de suas atribuições, ao desenvolver uma função própria do Senado.

Ao final, acordaram os Ministros do Supremo Tribunal Federal, por maioria dos votos, quanto ao cabimento da medida preventiva, tendo sido vencidos os Ministros Xavier de Albuquerque, Bilac Pinto e Eloy da Rocha, os quais, entretanto, acompanharam aquela maioria para, no mérito, conceder, por unanimidade, a medida preventiva para suspender a execução das normas de aparente inconstitucionalidade.

Posteriormente, em novembro de 1997, a requerimento do Presidente da República, das Mesas do Senado Federal e da Câmara dos Deputados, os Ministros do Supremo Tribunal Federal analisaram a possibilidade do deferimento de medida cautelar em sede da Ação Declaratória de Constitucionalidade $\mathrm{n}^{\mathrm{o}} 4$.

A cautelar foi deferida em parte, por maioria dos votos, para suspender até o julgamento final da ação, com efeito ex nunc e eficácia vinculante, a concessão de tutela provisória contra a Fazenda Pública como também os efeitos futuros das decisões já proferidas nesse sentido. Vencidos os Ministros Ilmar Galvão e Marco Aurélio, os quais a indeferiram.

A favor da concessão da medida, o Ministro Nelson Jobim entendeu que a plena aplicação da lei controvertida até a pronúncia da decisão definitiva pelo Supremo Tribunal Federal evita o agravamento do estado de insegurança ou incerteza jurídica, sendo dissipadas as distorções que possam ocorrer no território brasileiro no que diz respeito à vigência de normas constitucionais ou inconstitucionais.

Por outro lado, o Ministro Marco Aurélio, defendendo o seu voto vencido argumentando que, com a concessão dessas medidas, o que se almejava, na verdade, era a suspensão dos atos judiciais formalizados em lides em curso, sob a nomenclatura e a eficácia de tutela antecipada, sem que o 
Supremo Tribunal Federal decidisse caso a caso. Violando o princípio do devido processo legal, o que se queria era alcançar o acesso imediato ao Supremo Tribunal Federal, para que julgasse as tutelas sem o conhecimento das balizas que serviram de base aos julgadores, nas análises dos casos concretos, substituindo-se aos Regionais no exame de decisões precárias de primeira instância.

Assim, ainda de acordo com o Ministro Marco Aurélio, as decisões dos juízes inferiores seriam ignoradas para que fosse respeitada aquela proferida pelo Supremo Tribunal Federal, caracterizando, nesse contexto, uma supressão das etapas processuais, cujo cumprimento é imprescindível para a garantia da regularidade processual; a concessão da medida cautelatória geraria, nesse sentido, a sustação de todos os processos, porque vinculados estariam à decisão ditada pelo Supremo.

O Conselho Federal da Ordem dos Advogados do Brasil ajuizou em 03 de julho de 2000, por intermédio de seu Presidente, a Ação Direta de Inconstitucionalidade $\mathrm{n}^{\circ} 2258-0$ com o objetivo de questionar a legitimidade constitucional do parágrafo 2 을 artigo 11 e dos artigos 21 e 27 da Lei $\mathrm{n}^{\circ} 9.868 / 99$, os quais tratam, respectivamente, sobre a possibilidade de repristinação da norma quando concedida a medida cautelar em Ação Direta de Inconstitucionalidade, sobre a determinação da suspensão do julgamento dos processos que envolviam a aplicação da lei ou do ato normativo objeto da Ação Declaratória de Constitucionalidade até o seu julgamento definitivo, quando fosse concedida liminar, e, por fim, sobre a possibilidade de restrição dos efeitos da decisão em ambas as ações constitucionais.

A alegação apresentada pelo Conselho Federal da Ordem dos Advogados do Brasil em relação ao artigo 21 do diploma supramencionado teve como fundamento a violação do princípio constitucional à segurança jurídica, mais especificamente para considerar que a inconstitucionalidade decorre da violência ao artigo 5º, incisos XXXVII e LIV, da Lei Fundamental, pois permite seja afastada a controvérsia (o julgamento dos processos) de seu foro próprio, de seu juiz natural, com a quebra do devido processo legal. Afirmou que fora retirada dos juízes de primeiro grau a competência que a própria Constituição Federal lhes outorgou: exercer o controle difuso de constitucionalidade, e, com isso, preteriu-se a norma fundamental do ordenamento jurídico em detrimento da vontade do legislador infraconstitucional. 
No curso da petição inicial o Conselho Federal considerou que não há autorização constitucional para o Supremo Tribunal Federal suspender o curso de ações que tramitam perante juiz ou tribunal, não obstante a dignidade, competência, seriedade e imparcialidade de todos os seus membros, cuja competência, em última análise, decorre da Constituição Federal, tendo em vista não haver autorização constitucional para, sem recurso, paralisarem-se os processos.

Analisados os argumentos que preponderaram nas discussões iniciais acerca da legitimidade constitucional da cautelar nas ações de controle concentrado de constitucionalidade, vejamos quais os critérios normativos para a sua concessão no sistema jurídico brasileiro.

\subsection{Aspectos Normativos}

A Constituição Federal de 1988, ao dispor sobre as competências do Supremo Tribunal Federal, atribuiu-lhe, dentre outras, a de processar e julgar originariamente o pedido de medida cautelar na Ação Direta de Inconstitucionalidade, de acordo com o seu o artigo 102, I, $p$.

A Lei $\mathrm{n}^{\circ}$ 9.868, de 10 de novembro de 1999, que dispõe sobre o processo e julgamento da Ação Direta de Inconstitucionalidade e da Ação Declaratória de Constitucionalidade perante o Supremo Tribunal Federal, previu uma seção específica sobre a concessão de medida cautelar nessas ações de controle concentrado de constitucionalidade de normas.

Adotando como referência as normas supracitadas, a concessão de liminares deve ocorrer após a manifestação, no prazo de 05 (cinco) dias, dos órgãos ou autoridades dos quais emanou a lei ou ato normativo objeto da ação, sendo concedida desde que presentes o periculum in mora e o fumus boni iuris, com o objetivo de suspender ou impor, ainda que provisoriamente, a eficácia do preceito normativo que subsidiou a demanda.

A concessão das liminares posterior às manifestações das autoridades competentes justifica-se pela necessidade do Relator do processo formar a sua convicção, fundamentalmente porque sobre o seu objeto recai um relevante interesse de ordem pública, diretamente relacionado à manutenção da ordem no sistema jurídico, a partir da preservação da supremacia constitucional. Entretanto, em caso de urgência, a cautelar pode ser deferida de imediato, sem a oitiva do requerido, tendo em vista a aparente 
inconstitucionalidade de uma lei que, em não sendo suspensa in continenti, poderá gerar efeitos irreversíveis para a sociedade.

Tal medida deve ser concedida por um quorum qualificado pela maioria absoluta dos Ministros do Supremo Tribunal Federal, desde que presentes oito deles. No período em que o Supremo Tribunal Federal estiver em recesso, poderá o Relator decidir sobre o pedido de medida cautelar, devendo essa decisão ser ratificada pelos demais integrantes da Corte nas primeiras sessões após o recesso.

Se julgar indispensável para a formação da sua convicção e segurança na decisão, o Relator ouvirá o Advogado Geral da União e o Procurador-Geral da República, no prazo de três dias.

Como regra essa manifestação ocorre após a concessão da medida, mas pode acontecer antes dessa, no tríduo legal, bem como na sessão designada para o seu julgamento, quando será feita oralmente, pelos representantes judiciais dos requerentes e órgãos responsáveis pela expedição do ato, garantindo, assim, a todos os Ministros o conhecimento dos argumentos que fundamentam as alegações estabelecidas por ambos os polos do processo.

O efeito da decisão que concede a medida cautelar é ex nunc, não retroagindo para afetar fatos passados, tendo em vista a segurança jurídica que pode ser abalada se a decisão de mérito for diversa daquela proferida provisoriamente.

O efeito ex tunc, retroativo, pode ser excepcionalmente declarado, desde que casos considerados extremos o justifiquem. Em verdade, o texto legal deixou margem para que o Relator do processo, através de uma avaliação subjetiva, conceda ou não tal efeito retroativo às cautelares, pois não restaram determinados legalmente os parâmetros que devem nortear a retroatividade da medida.

A medida cautelar produz, ainda, efeito repristinatório em relação à norma anterior que havia sido revogada por aquela que está sendo objeto da ação constitucional. Pode, entretanto, o Supremo Tribunal Federal deixar de atribuir tal efeito, desde que assim se manifeste expressamente, quando considerar que a norma a ser repristinada agrida mais à ordem constitucional do que àquela que está sendo objeto de questionamento perante uma ação constitucional. 
Antes da apreciação do pedido liminar, pode o julgamento do processo ser antecipado, desde que relevantes a matéria e o seu significado para a ordem social e a segurança jurídica, critérios esses definidos de acordo com a avaliação subjetiva do Relator.

O abreviamento do curso do processo para que seja proferida a decisão definitiva se justifica quando não existirem dúvidas acerca da legitimidade ou ilegitimidade constitucional da norma impugnada, tendo em vista a necessidade de se preservar a unidade jurídica que regulamenta as relações sociais, pois o que se verifica, muitas vezes, é que, quando concedidas, as cautelares se eternizam no Supremo Tribunal Federal, especialmente porque o legislador não se preocupou em fixar um prazo para o julgamento definitivo da ação, contrariando assim, o princípio da segurança jurídica, tendo em vista que uma matéria controvertida e de interesse público imediato permanece regulamentada durante anos por uma decisão que, além de provisória - portanto, modificável a qualquer tempo -, ao tornar-se definitiva poderá adotar delineamentos totalmente contrários àqueles que fundamentaram a decisão acautelatória.

A parte dispositiva de decisão proferida em sede de cautelar deve ser publicada no prazo de 10 (dez) dias, e possui efeito erga omnes, oponível contra todos.

Dispõe o artigo 21, da Lei no 9.868/99, que o Supremo Tribunal Federal poderá conceder cautelar na Ação Declaratória de Constitucionalidade, devendo os juízes e Tribunais suspender o julgamento dos processos que estejam relacionados à lei ou ao ato normativo de constitucionalidade incerta, até o seu julgamento definitivo, que deverá ocorrer no prazo de 180 (cento e oitenta) dias, contados a partir do deferimento do pedido sob pena de perda de sua eficácia.

Esse prazo estipulado para a vigência das cautelares deveria ter sido definido também para as Ações de Inconstitucionalidade, posto que o julgamento sobre a constitucionalidade de leis ou atos normativos deve ter prioridade e primar pela celeridade, uma vez que envolve a hegemonia do sistema jurídico.

Assim, enquanto na Ação Direta de Inconstitucionalidade as cautelares vigoram até que seja proferida a decisão definitiva pelo Supremo Tribunal Federal, na Ação Declaratória de Constitucionalidade o legislador determinou o prazo de 180 dias para que seja julgado o mérito, ressaltando-se 
o efeito vinculante da decisão que concede a cautelar, de acordo com a qual todos os julgamentos dos processos em instâncias inferiores que envolvam a aplicação da lei ou ato normativo objeto da ação devem ser paralisados, para aguardar o julgamento definitivo da ação constitucional.

Martins admite que esse prazo definido pelo artigo 21, da Lei $\mathrm{n}^{\circ}$ 9.868/99, poderá ser dilatado em face do acúmulo de processos no Supremo Tribunal Federal, de modo a impossibilitar um julgamento com maior brevidade, porém, o prazo para a manifestação dos interessados e nomeados pela lei é preclusivo, pois independe da atuação do Supremo Tribunal Federal, mas, tão somente, do interesse das partes. (MARTINS; MENDES, 2001, 283).

Ressalte-se que se a tutela definitiva não for concedida passados os 180 dias previstos legalmente, e não havendo o pedido de dilatação desse prazo, a tutela provisória deverá perder a sua eficácia, restando às partes aguardarem o andamento processual ordinário, que culminará com a decisão definitiva.

A concessão de medidas cautelares nos processos de controle concentrado de constitucionalidade de normas deve também estar pautada em fundamentos de cunho teórico, que serão utilizados pelo juiz, ainda que de forma não manifesta, ao aquiescer ou discordar da realização dessas medidas provisórias no curso processual, conforme segue a análise.

\section{A Ilegitimidade da Concessão das Medidas Cautelares em Sede da Ação Direta de Inconstitucionalidade: uma análise sob a perspectiva de Victor Comella}

A função atribuída aos juízes constitucionais limita-se à possibilidade de declarar a ilegitimidade constitucional de uma norma ou ato normativo, não lhes sendo permitido criar em suas sentenças textos normativos capazes de regular a vida em sociedade.

Enquanto cabe ao Legislativo transformar em conteúdos normativos o querer social, a justiça constitucional deve retirá-las do conjunto regulador das relações sociais quando não mais se coadunarem ao elemento de maior expressão dessa vontade majoritária da sociedade, que é a Constituição. 
Essa divisão de atribuições foi muito bem exposta por Moreira (1995), de acordo com o qual a vontade política da maioria governante de cada momento não pode prevalecer sobre a vontade da maioria constituinte incorporada na lei fundamental, pois a limitação da vontade da maioria ordinária decorre da supremacia de uma maioria mais forte.

No exercício da jurisdição constitucional, cabe aos juízes constatarem se os limites traçados pela Carta Constitucional foram respeitados pelo legislador ordinário ao formular as disposições normativas infraconstitucionais, pois, no mais das vezes, a realidade que se apresenta é a de que o conteúdo das normas publicadas representa a vontade de um segmento da sociedade, como a de um partido político ou mesmo de grupo empresariais, por exemplo, e não a da maioria dos integrantes do grupo social.

Dessa forma, as decisões proferidas pelos juízes constitucionais são, na verdade, medidas de defesa dos interesses sociais regulamentados pela Constituição, os quais podem ser desrespeitados durante o exercício da função legislativa e executiva quando permitem a prevalência dos objetivos e aspirações de um grupo específico em detrimento do todo social.

Critérios devem ser observados para que se evite a politização nas decisões da justiça constitucional, a exemplo de os juízes constitucionais serem escolhidos em razão de sua formação cultural e ideológica diversas, capazes de representarem se não de todos, pelo menos da maioria, dos segmentos da sociedade nas suas decisões, e não em função de um critério político-partidário. As decisões devem refletir os interesses da sociedade, instituídos constitucionalmente, e não os de natureza partidária.

Adotando os ensinamentos de Comella (1997), pode-se afirmar que as leis gozam de presunção moderada de validade, pois nas situações nas quais a constitucionalidade da norma não seja manifesta presume-se a compatibilidade da lei à Constituição e, no caso de dúvida, o juiz deve decidir pela sua constitucionalidade sempre que existir uma forma de interpretá-la de acordo com o texto constitucional, e desde que não haja provas que lhe sejam contrárias, já que a presunção pode ser destruída se existirem elementos que a contradigam - quanto maior for o rigor para a caracterização desses elementos, mais forte será a presunção da legitimidade constitucional da norma.

Presunção moderada de constitucionalidade porque não se deve impor ao impugnante o encargo de provar que a inconstitucionalidade da 
lei é manifesta, pois se assim fosse necessário não mais existiria qualquer contribuição judicial para a deliberação pública, e o juiz somente invalidaria as leis claramente inconstitucionais, e assim não mais se discutiriam os princípios estruturadores da sociedade e os interesses priorizados e positivados através das normas, os quais estão em constante mutação, em razão da contínua busca pelo desenvolvimento e aperfeiçoamento que identifica as sociedades modernas.

Tal presunção de validade está relacionada ao fato dessas terem sido elaboradas por integrantes do órgão representativo dos vários setores sociais, os quais, através de procedimento democrático, puseram em questionamento variados interesses e direitos coletivos como o direito à vida, à liberdade de expressão, ao sufrágio e à educação.

Esse processo democrático possui mais legitimidade para criar decisões corretas sob o aspecto moral do que qualquer outro tipo de procedimento alternativo, e isso ocorre em razão da participação, tanto na deliberação como na tomada de decisões, daqueles que serão o alvo das políticas provenientes desse procedimento.

A partir da discussão estabelecida entre os vários setores sociais e, finda essa, com a decisão emanada por todos, poder-se-á conhecer a verdade que integra o seio social, a verdade moral, possibilitando esse processo deliberativo que toda e qualquer decisão porventura adotada pelos poderes públicos, esteja calcada em bases consideradas relevantes, não apenas para a sociedade, mas, principalmente, pela própria sociedade, tornando-se, assim, de mais fácil conhecimento os direitos e as liberdades que fundamentam, com mais legitimidade, os valores da justiça e moralidade, motivadores da criação da ciência jurídica.

Embora esse procedimento democrático não garanta que as decisões adotadas sejam sempre justas, posto que o órgão parlamentar no momento da discussão e aprovação do conteúdo normativo poderá preteri-lo em prol da vontade de uma facção política, é, no entanto, o que melhor proporciona o alcance da justiça na adoção dessas normas, pois dele participam, através de sua voz e voto, os representantes das pessoas sobre as quais incidirão os resultados políticos.

Nesse sentido a teoria de John Rawls abordada por Comella (1997, p. 164), pela qual se define como uma justiça processual imperfeita, uma vez que não está garantida a justiça nas decisões legislativas, mas, ainda que 
apresente falhas, tende a proporcionar decisões mais corretas do que qualquer outro procedimento alternativo, justamente porque se perfaz a partir da participação dos interessados, ainda que através dos seus representantes, na tomada de decisões.

Além da participação dos interessados na definição dos valores que fundamentarão as normas elaboradas, deve ser aplicada a regra da maioria nesse processo deliberativo, de acordo com a qual todas as heterogeneidades fomentadas serão discutidas, e destas serão extraídas as soluções capazes de melhor coadunar o querer da minoria aos da maioria, sem que isso implique num necessário convencimento do grupo minoritário de que a decisão adotada lhe tenha sido a mais benéfica, mas, sim, que foi capaz de melhor harmonizar ambos os interesses, evitando, nesse contexto, eventuais prejuízos e conflitos intrasociais.

Dialogando com o renomado jurista argentino Carlos Santiago Nino, Comella (1997) discute os argumentos utilizados para justificar a instituição do controle de constitucionalidade realizado pelos juízes, pois, pressupõe-se, deva ser a democracia defendida com base nos valores epistêmicos.

Inicialmente, para que o procedimento democrático represente o ideal de um processo deliberativo, sendo revestido de perfeição, necessário seria que a discussão estabelecida entre os atores sociais culminasse com a unânime aceitação da decisão tomada, pois quanto maior o número de pessoas apoiando tal decisão, maior a probabilidade de a mesma corresponder a todos os interesses sociais em questão, mas, como não se torna sensato discutir indefinidamente sobre o que deve ou não ser normatizado, até que se alcance a hegemonia das decisões, deve-se priorizar a regra da maioria.

Existe uma situação fática passível de mudança, denominada status quo, a qual não pode preponderar sobre a necessidade de inovações normativas, regulamentadoras das modificações sociais, sentidas em razão do constante aprimoramento do pensamento e do querer humano.

Diante desse contexto, não se pode permitir que a minoria que prefere manter o status quo, não desejando mudanças, prevaleça sobre o querer da maioria ávida por transformações e desenvolvimento. Justifica-se, portanto, a não exigência da unanimidade - que é de difícil alcance - para a aprovação de um novo texto jurídico, sendo suficiente a aprovação majoritária. 
Assim, a decisão democrática teria vantagem epistêmica sobre a judicial, pelo fato de aquela se perfazer a partir da deliberação e participação dos afetados nas decisões que assegurarão os chamados direitos a priori, que são: o direito à vida, à liberdade de expressão, ao sufrágio e à educação; ao passo que nessa os juízes refletem isoladamente acerca de suas decisões, sem a contribuição da discussão pública.

A despeito dessa vantagem epistêmica que o processo democrático possui sobre o controle judicial, Comella (1997) ressalta a contradição da teoria de Nino, porque esse considera que o controle judicial das leis deva ser exercido apenas nos casos nos quais forem violados os direitos que ensejam a caracterização do valor epistemológico da democracia, isto é, os direitos a priori supramencionados.

Mas se o valor epistêmico caracteriza o processo legislativo por que, então, conferir a outro órgão a prerrogativa de analisar a legitimidade constitucional de uma norma? O controle de constitucionalidade exercido pelos juízes não se justificaria pela sua suposta superioridade em relação aos que realizam as demais funções estatais, mas sim pelo fato de que há contribuição para a manutenção da cultura pública constitucional, pois os princípios norteadores da sociedade estão sendo sempre discutidos, resultando em melhor embasamento para o próprio legislador ao elaborar as normas.

Ademais, a possibilidade de saber que a lei poderá ser questionada na esfera judicial pela minoria que não teve os seus interesses atendidos pela decisão normativa, e que poderá ser declarada inconstitucional, faz com que o legislador atribua mais respeito ao processo democrático.

No que tange à ausência de deliberação pública durante o processo de verificação da legitimidade constitucional normativa, importante observar que os juízes do Tribunal fazem parte do eleitorado e, portanto, participam da deliberação coletiva, como cidadãos. Por outro lado, o Tribunal é um órgão colegiado, e a decisão é o resultado de uma deliberação entre os juízes que o integram. Por fim, o debate parlamentar que precedeu à aprovação de uma lei é conhecido pelos juízes, em seus aspectos fundamentais, através das argumentações desenvolvidas pelas distintas partes no processo.

Por todo o exposto, o controle judicial não deve ser considerado como um entrave ao procedimento democrático que identifica a elaboração normativa, mas, ao contrário, o reforça; entretanto, tal controle judicial sofre restrições e, talvez, a mais importante de todas seja deferência que o juiz 
deve fazer às produções normativas, presumindo-as constitucionais, não realizando, portanto, juízos prévios acerca da sua incompatibilidade com a Carta Suprema, haja vista que essas normas representam, de forma mais legítima, o querer social.

Para que uma medida cautelar seja concedida em sede de Ação Direta de Inconstitucionalidade é preciso que inexistam interpretações que tornem a lei que está em questionamento compatível ao texto constitucional, pois, de outro modo, deverá o juiz optar pela interpretação que se adaptar aos preceitos constitucionais, não concedendo assim, a cautelar requerida.

A presunção quanto à legitimidade da norma deve ser utilizada para permitir a tomada de decisões nas quais impera a incerteza, sendo, no entanto, passível de refutação se existir provas que a contradiga, posto que quanto maior for o rigor para a caracterização dos elementos contrários a tal presunção, mais força esta terá.

Nesses termos, o que deveria pautar a atividade jurisdicional ao conceder uma medida cautelar no processo de Ação Direta de Inconstitucionalidade seria a admissão da fraca presunção de constitucionalidade da lei questionada, diante da inexistência de interpretações normativas compatíveis ao texto fundamental, e da constatação de que o dispositivo legal seria resultado da manifestação de uma casta social e não da vontade social, ou, de acordo com Comella $(1997,160)$ :

en caso de duda, el juez debe decidir a favor de la constitucionalidad de la ley. Dicho de otra manera: el juez sólo puede decidir a favor de la inconstitucionalidade si ésta no resulta dudosa. Para entender destruída la presunción de la ley se exige la aportación de elementos de juicio (argumentos) de suficiente peso que puedan justificar la creencia del juez de que se da una contradicción entre la interpretación correcta del texto legal impugnado y la interpretación correcta del texto constitucional.

Para que, ainda que provisoriamente, o juiz suspenda a aplicação de uma norma, torna-se imprescindível a observância de fundamentos consistentes para tanto, visto que tal suspensão gera insegurança no seio social, a partir da descrença dos cidadãos nos seus representantes, eleitos democraticamente, e que se fizeram presentes durante todo o processo de deliberação e aprovação legislativa, culminando com a produção da norma maculada pelo vício da inconstitucionalidade, portanto, contrária à vontade 
popular manifestada na Constituição Federal.

A lei aprovada para regulamentar as relações em uma sociedade deve tramitar por um processo de deliberação e aprovação democrática, durante o qual se fazem presentes os representantes dos mais diversos segmentos sociais, e que podem igualmente contribuir para a elaboração do texto normativo, sendo este, portanto, uma criação do grupo social.

Nesse contexto, o provimento dessa medida acautelatória em sede de Ação Direta de Inconstitucionalidade não se justificaria em razão do fato de que o juiz não estaria fazendo deferência ao produto da atuação democrática ao presumir a inconstitucionalidade normativa, durante a qual as vozes mais discordantes do grupo social se fizeram ouvir, podendo modificar o seu entendimento, ao final do processo, proferindo a decisão definitiva, desde que reste comprovada no processo a legitimidade constitucional do texto normativo impugnado.

\section{Conclusão}

As normas devem ser presumidas constitucionais, pois representam o querer social manifestado através de processo democrático de deliberação e aprovação, no qual participaram os mais diversos grupos que compõem o tecido social.

A declaração, ainda que provisória, da ilegitimidade constitucional normativa, implica na não aceitação dessa presunção de constitucionalidade da norma.

Questiona-se, na verdade, a representação parlamentar, isto é, o juiz, ao conceder uma cautelar para suspender a aplicação normativa, está manifestando, ainda que tacitamente, que o legislador não representou o querer social e, portanto, aquele preceito não representa os valores democráticos, afrontando a Constituição brasileira, calcada que está na democracia.

Dificilmente, a não ser em situações extremas e excepcionais, o juiz constitucional tem instrumentos para perceber, numa análise inicial do processo, que a norma em questão violou os princípios básicos norteadores da sociedade, presumindo-se, assim, a sua inconstitucionalidade.

Diante de tudo o que fora pontuado neste ensaio, pode-se mesmo afirmar que a inconstitucionalidade não deve ser presumida, mas sim, deve ser sempre comprovada.

Assim, corroborando os ensinamentos de Comella (1997), em caso de dúvida ou diante de um provimento provisório, o juiz deverá decidir semResenha Eleitoral (Florianópolis), v. 20, n. 2, p. 127-148, ago./dez. 2016 
pre pela constitucionalidade da norma até que reste comprovado o contrário, a não ser que esteja diante de uma norma com uma fragilíssima presunção de constitucionalidade, juízo esse que requer uma demonstração clarividente nos autos processuais para que, diante desse contexto, não quede abalada a força da Constituição como norma basilar no sistema jurídico, bem como a legitimidade conferida pela sociedade aos seus representantes eleitos democraticamente para elaborar normas suficientemente capazes de traduzir os anseios de um dado contexto coletivo a partir da sua interpretação constitucional.

\section{Referências}

CAPPELLETTI, Mauro. O Controle judicial de constitucionalidade das leis no Direito Comparado. 2. ed. Porto Alegre: Sergio Antonio Fabris Editor, 1992. COMELLA, Victor Ferreres. Justicia Constitucional y democracia. Madri: Centro de Estudios Politicos y Constitucionales,1997.

KELSEN, Hans. Teoria Pura do Direito. São Paulo: Martins Fontes, 1999.

LLORENTE, Francisco Rubio. La forma del Poder (Estúdios sobre La Constitución). Madri: Centro de Estudios Constitucionales, 1997.

MARTINS, Ives Gandra da Silva; MENDES, Gilmar Ferreira. Controle Concentrado de Constitucionalidade: comentários à Lei no $\mathbf{9 . 8 6 8}^{\text {, de }}$ 10-11-1999. São Paulo: Saraiva, 2001.

MOREIRA, Vital. Princípio da maioria e princípio da constitucionalidade: legitimidade e limites da justiça constitucional. In: Legitimidade e Legitimação da Justiça Constitucional. Lisboa: Coimbra Editora, 1995.

SUSTEIN, Cass R. The Partial Constitution. Cambridge, Massachusetts e Londres, Inglaterra: Harvard University Press.

VELOSO, Zeno. Controle jurisdicional de constitucionalidade: atualizado conforme as Leis n⿳⺈ 9.868/99 e 9.882/99. 2.ed. Belo Horizonte: Del Rey, 2000.

Juliana Rodrigues Freitas - Doutora em Direito (2010 - UFPA/ Università di Pisa - Itália). Mestre em Direitos Humanos (2003 - UFPA). Pós-Graduada em Direito do Estado (2006 - Universidade Carlos III de Madri - Espanha). Atua como Consultora Jurídica e Advogada na área eleitoral e municipal. Professora da Graduação e Mestrado em Direito do Centro Universitário do Estado do Pará - CESUPA. Pesquisadora do Observatório de Direito Eleitoral do CNPQ, promovido pela Universidade do Estado do Rio de Janeiro UERJ. Membro Fundadora da Academia Brasileira de Direito Eleitoral e Político - ABRADEP. Avaliadora de artigos do Espaço Jurídico Jornal of Law. 